\title{
KELUARGA SEBAGAI WAHANAN PERTAMA DAN UTAMA PENDIDIKAN KARAKTER ANAK
}

\begin{abstract}
Ni Wayan Suarmini
Abstrak

Keluarga merupakan tempat pertama dan utama bagi pertumbuhan dan perkembangan seorang anak, sehingga peran dan fungsi keluarga menjadi sangat penting dan bertanggung jawab terhadap tumbuh kembang anak.Keluarga merupakan tempat yang paling awal dan efektif untuk menjalankan fungsi Departemen Kesehatan, Pendidikan, dan Kesejahteraan. Apabila keluarga gagal untuk mengajarkan kejujuran, semangat, keinginan untuk menjadi yang terbaik, dan kemampuan-kemampuan dasar, maka akan sulit sekali bagi institusi-institusi lain untuk memperbaiki kegagalan-kegagalannya.Kegagalan keluarga dalam membentuk karakter anak akan berakibat pada tumbuhnya masyarakat yang tidak berkarakter. Oleh karena itu, setiap keluarga harus memiliki kesadaran bahwa karakter bangsa sangat tergantung pada pendidikan karakter anak di dalam keluarga.
\end{abstract}

Kata kunci :Keluarga , karakter

Manusia secara kodrati terlahir sebagai makhluk individu dan makhluk sosial. Manusia sebagai individu memiliki kekhususaan, ciri khas, kepribadian, karakter, yang tentunya berbeda antara yang satu dengan yang lainnya. Manusia disebut sebagai makhluk yang unik, karena dari semua individu yang ada di muka bumi ini tidak satupun sama. Dalam kehidupan individu juga harus terjaga keharmonisan sebagai individu, yaitu dimulai dari berfikir yang jujur dan benar, berkata yang jujur dan benar, dan berperilaku yang jujur dan benar. Dengan kata lain bahwa kehidupan harmonis bagi seorang individu adalah harmonis antara pikiran, perkataan dan tindakan. Semua itu sangat pribadi, karena hanya mereka yang mengetahui, merasakan, dan melakukan. Satunya pikiran, perkataan dan tindakan dalam Hindu digambarkan dalam ajaran Tri Kaya Parisuda.

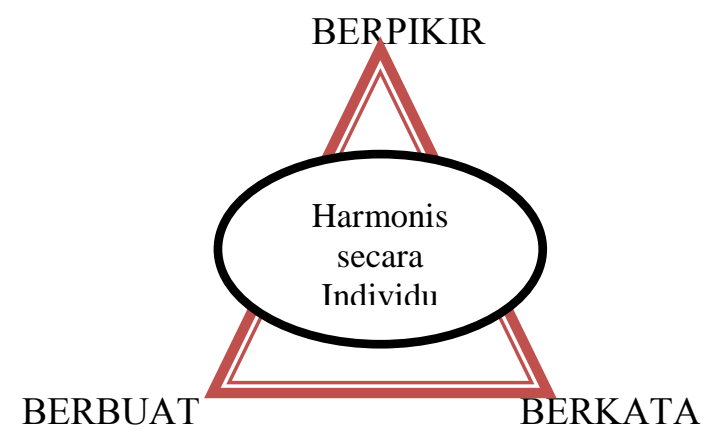

Gambar: 1. Ajaran Tri Kaya Parisuha Hindu

jsh Jurnal Sosial Humaniora, Vol 7 No.1, Juni 2014 
Manusia tidak dapat hidup terpisah dari manusia lainnya, manusia akan memiliki makna apabila hidup di tengah-tengah manusia lainnya. Keharmonisan secara individu akan sangat memudahkan manusia menyesuaikan diri dengan lingkungannya.

Manusia secara kodrati juga sebagai makhluk sosial. Sebagai makhluk sosial seseorang individu harus hidup berdampingan dengan orang lain, bahkan makhluk hidup lainnya. Kehidupan sosial, seperti berteman, berkeluarga, bermasyarakat, bersuku, dan berbangsa bernegara. Kehidupan kelompok dapat mempengaruhi kehidupan individu, demikian juga sebaliknya. Oleh karena itu terjadi kehidupan dalam suatu komunitas, artinya berkelompok bagi yang memiliki kesamaan visi, kepentingan yang sama, kesamaan daerah asal, kesamaan keluarga, bahkan kesamaan darah, dan sebagainya. Terjadilah banyak bentuk komunitas dalam masyarakat. kehidupan pribadi tetap dapat terwujud, namun dalam hal-hal tertentu harus menurunkan atau melakukan penyesuaian dengan komunitasnya. Kalau tidak terjadi toleransi, adaptasi, dan menurunkan tempo individunya, maka tidak akan terjadi kehidupan kelompok tersebut

Kehidupan sosial dapat harmonis apabila terwujud dan saling menjaga hubungan baik dengan Tuhan, sesama, dan lingkungan. Artinya mannusia harus menjaga hubungan keharmonisan dengan Tuhan dengan menjalankan ajaran kebenaran yang diturunkan ke muka bumi ini, melalui agama yang dianut masing-masing individu. Agama sifatnya individual, karena tergantung dari kedalaman seseorang menangkap makna ajaran untuk dipahamkan dan menjadi tingkat keimanan masing-masing individu dalam menjalankan ajaran. Keimanan itu tidak dapat diukur dari cassingnya saja, seperti penampilan phisik, pakaian, bahkan kata-katanya. Oleh karena keimanan seseorang hanya dirinya sendiri dan Tuhan yang mengetahui kebenarannya. Menjaga hubungan baik dengan sesama, maknanya kehidupan seseorang individu harus saling membantu, menghargai, menghormati, toleransi, gotong royong dengan sesama individu lainnya. Manusia sebagai makhluk Tuhan, berarti sama di Mata Tuhan, maka sebagai manusia harus memandang orang lain juga sama, sebagaimana Tuhan memandang semua ciptaanNya. Manusia bagaikan debu dihamparan bumi ini, apa yang dapat 
disombongkan, maka tumbuhkan sikap saling bekerjasama lebih penting dari sekedar memenuhi kepentingan pribadi. Menjaga hubungan baik dengan lingkungan, mengandung makna bahwa manusia tidak hidup sedirian di bumi ini. Terdapat makhluk hidup lain sebagai partner yang saling membutuhkan untuk menjalani kehidupan di bumi ini. Manusia tidak bisa hidup layak tanpa makhluk hidup lain itu. Contoh, semua makanan yang dimakan manusia berasal dan dihasilkan oleh tumbuhan dan hewan. Di bumi ini, jikalau tumbuhan saja tidak bisa tumbuh, hewan mana yang mampu bertahan hidup, jikalau hewan tidak mampu bertahan hidup, manusia mana yang bisa hidup. Oleh karena itu manusia sebagai makhluk yang paling sempurna di antara makhluk hidup lainnya itu, tidak dibenarkan sewenang-wenang terhadap partner hidupnya tersebut. Kelebihan manusia dianugerahi akal dan pikiran oleh Tuhan Yang Esa, seharusnya digunakan untuk mencapai keharmonisan dalam mengarungi kehidupan ini. Tetapi kenyataannya bahwa akal dan pikiran itu digunakan untuk melakukan hal-hal untuk memenuhi kepentingan dirinya yang sesaat itu. Melakukan eksploitasi terhadap alam lingkungan baik phisik maupun sosial. Sering digunakan untuk mengakali teman, sahabat, dan orang lain untuk memenuhi kepentingan sendiri. Kadang-kadang juga terjadi bahwa dirinya sendiri saja sering dibohongi, apalagi terhadap orang lain, dan makhluk hidup lainnya. Ibaratnya manusia sendiri menyiapkan kuburanya sendiri di muka bumi ini. Kehidupan harmonis yang didambakan oleh umat manusia tidak akan pernah terwujud selama kepentingan pribadi dan kelompok kecil yang mendasari perbuatannya. Kehidupan harmonis dapat tercapai apabila terjalin hubungan baik dan harmonis dengan ketiga partner hidup tersebut. Sebenarnya akal dan pikiran yang dianugerahi itu untuk mengetahui perbuatan baik dan buruk, sehingga dapat memperbaiki perbuatan buruk tersebut. Akal itu menghasilkan suatu yang kreatif, inovatif, sehingga menjadi produktif. Manusia sering menggunakan fikirannya untuk mengatur kecerdasannya, padahal yang seharusnya adalah kecerdasan itulah yang mengatur fikiran. Sebagaimana kata orang bijak, apabila manusia diatur oleh fikiranya, maka perbuatan jahat yang akan terjadi, sebaliknya apabila kecerdasan yang mengatur fikiran, maka perbuatan baik yang akan terjadi. 
Dikarenakan fikiran itu hawa yang bebas, artinya bisa menjadi paling baik, namun bisa menjadi paling jahat. Contoh dalam suatu perbuatan jahat, maka yang dihukum paling berat adalah otak pelakunya (pemikirnya), juga termasuk pelakunya pula.

Menjaga hubungan baik yang telah dipaparkan di atas tercantum dalam ajaran Hindu yang disebut Tri Hita Karana. Sebagaimana digambarkan di bawah ini.

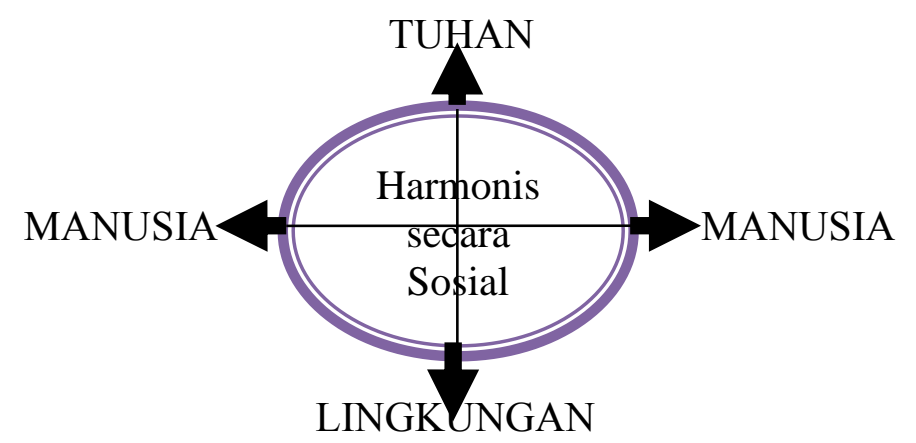

Gambar: 2. Ajaran Tri Hita Karana Hindu

Keluarga merupakan sistem sosial terkecil dalam masyarakat, yang terdiri dari ayah, ibu, dan anak. Keluarga sebagai lembaga pendidikan pertama dan utama bagi anak. Maknanya bahwa keluarga sebagai peletak dasar-dasar pendidikan dalam pembentukkan karakter anak. Anak sebagai generasi penerus kehidupan keluarga kelak, sehingga anak sering dipandang sebagai cerminan keluarga. Hal ini menunjukkan bahwa pendidikan dalam keluarga menjadi sangat penting mendapatkan perhatian dari anggota keluarga yang lebih dewasa. Sebenarnya bahasa ibu sangat berpengaruh terhadap pembentukkan nilai-nilai moral kepada anak. Bahasa ibu (bahasa daerah) senantiasa mengandung tata krama, sopan santun, dan unggah ungguh untuk kehidupan sosial anak. Bahasa ibu atau bahasa daerah ditinggalkan oleh generasi sekarang, terlihat jelas bagaimana anak berbicara kepada orang tua atau orang yang lebih tua atau orang yang dituakan. Orang tua menjadi model bagi tumbuh kembang anak-anak dalam keluarga dan masyarakat. Meniru merupakan faktor yang berkembang pada anak, karena sebagai suritauladan. Sebagaimana dikemukakan oleh Ki Hajar dewantara tokoh pendidikan Indonesia bahwa ing ngarso sung tulodo, ing madya mangun karsa, dan tut wuri handayani sebagai pendidikan karakter. 
Kehidupan keluarga yang harmonis menghasilkan anak-anak bangsa yang bermoral dan berakhlak mulya. Demikian juga sebaliknya. Oleh karena itu manusia sejak awal sudah benar melakukannya, seperti diawali dengan saling mengenali satu dengan yang lainnya, proses pemilihan, dan menentukan pilihan sebagai pasangan hidup. Namun dalam perjalanan kehidupan keluarga muncul kembali kehidupan individu yang ego, sehingga sering terjadi keluarga tidak harmonis lagi. Korbanya adalah anak-anak mereka, apapun alasanya yang menjadi korban sudah pasti anak. Orangtua tidak bisa tergantikan oleh siapapun, dan juga apapun. Dengan berakhirnya kehidupan keluarga yang harmonis, maka hilang pulalah pendidikan anak yang berkarakter dalam keluarga tersebut. Orangtua diharapkan tidak mengedepankan egonya dalam memecahkan permasalahannya. Mengedepankan pendidikan anak, kebutuhan anak, dan kepentingan anak, karena anak itulah generasi keluarga dan bangsa ini. Martabat keluarga pembentuk bangsa dapat diukur dan terlihat dari moral generasi mudanya.

Keluarga yang mendidik anak-anaknya dengan baik akan menghasilkan generasi bangsa yang baik pula. Maka kondisi bangsa ini juga tercermin dari keharmonisan kehidupan keluarga-keluarga dalam masyarakat. Anak itu harus dipandang sebagai subyek bukan obyek, artinya kepentingan atau kebutuhan anak yang pertama dan utama yang dipenuhi sebelum memenuhi kebutuhan orang dewasa dalam keluarga. Anak-anak mendapat contoh dari orang dewasa, karena di suatu sisi yang lain orang dewasa mengeksploitasi anak-anak untuk kepentingannya. Orang dewasa harus pula mendapatkan pengembangan akses dalam memenuhi kebutuhan hidupnya, baik kebutuhan phisik, sosial dan psikologis.

Di layar televisi belakangan ini sering kita melihat berbagai tontonan tindak kekerasan, pelecehan seksual dan tindak kriminal lainnya, baik terjadi dalam keluarga, di sekolah, maupun di lingkungan lain. Terutama tindak kekerasan bagi anak-anak, justeru terjadi pada tempat anak-anak melakukan aktivitas bermain. Peristiwa-peristiwa tersebut memunculkan pertanyaan di benak kita : "Apa yang terjadi dengan masyarakat dan bangsa ini? Bagaimana dengan pendidikan bagi 
genarasi bangsa ini, mengapa kejadian-kejadian itu terjadi pada lingkungan yang seharusnya memberikan perlindungan pada anak-anak. Mengapa dilakukan oleh orang-orang dekat dan kenal dengan baik oleh mereka ? Pertanyaan yang sama juga muncul ketika kita mengetahui berbagai tindak korupsi di lingkungan pemerintahan, BUMN, atau perusahaan swasta yang merugikan keuangan negara dalam jumlah hitungan yang tidak terbayangkan. Apakah pekerja bahkan pejabat memikirkan dirinya sendiri tanpa peduli dengan lembaga dan masyarakat yang seharusnya mendapatkan pelayanan dan hak-haknya sebagai warga negara.

Pejabat publik justeru tugasnya adalah melayani masyarakat, bukan meminta pelayanan. Lembaga dan program layanan itu diadakan karena untuk melayani kebutuhan masyarakat. Hal inilah yang harus disadari oleh pekerja bahkan pejabat publik, agar tidak salah menterjelamhan filosofi kerja yang digeluti tersebut. Mental orang dewasa sebagai pekerja dan pejabat, serta masyarakat harus mendapatkan penanganan yang lebih intensif. Bahkan dapat dilakukan revolusi mental, dengan pendekatan humanis. Mungkin dapat dimulai dari penggunaan bahasa, karena bahasa bukanlah sekedar sebagai alat komunikasi bagi masyarakat, melainkan bahasa adalah budaya. Artinya bahasa mengandung nilai-nilai kehidupan, tata krama (norma, kaidah), sopan santun maka penting untuk dilestarikan, ditingkatkan dan di kembangkan. Contohnya bahasa daerah ditinggal oleh anak-anak, maka hilang pula unggah-ungguh anak terhadap orang tua, orang lain, bahkan dengan orang yang dituakan. Bahasa Indonesia dibentuk dari berbagai bahasa daerah di tanah air, maka jangan sampai bahasa Indonesia ditinggal oleh orang-orang Indonesia. Bahasa ibu (daerah) dan bahasa Indonesia ditinggal sama artinya bangsa ini bubar dalam kesatuan.

Lihatlah contohnya Jepang, negara maju, modern, kaya, namun tetap santun dalam berinteraksi dengan orang lain, bangsa lain, mengapa ? Jepang mampu mempertahankan bahasa nasionalnya dalam berinteraksi dengan orang lain, baik di dalam negerinya maupun di luar negeri. Siapapun ke Jepang wajib bisa berbahasa Jepang. Itulah kekuatan Jepang untuk mempertahankan kelanggengan bahasanya, karena diyakini mengandung nilai-nilai luhur untuk kehidupan. 
Karaketer bangsa harus terlahir dari bangsa itu sendiri. Indonesia sebagai bangsa yang besar harus memiliki karakter Indonesia, bukan karakter lain. Maka penegakkan hukum, melestarikan bahasa (daerah dan Indonesia), mentaati ajaran agama mutlak dilakukan untuk revolusi mental masyarakat Indonesia. Tentu dimulai dari lembaga-lembaga pendidikan, lembaga atau organisasi-organisasi kemasyarakatan, pemerintah pada lembaga-lembaga, dan semua pihak warga negara Indonesia tanpa kecuali. Konsisten menerapkan aturan, sistem, dan ajaran agama. Karakter bangsa akan terwujud dengan sendirinya sebagai bangsa yang besar dan kaya sumber daya alam dan sumber daya manusia. Tinggal memoles dengan pendidikan yang benar, berdasarkan kepribadian Indonesia, maka akan menghasilkan tenaga kerja dan pekerja yang berkarakter Indonesia.

Sementara ini menjadi tidak jelas karakter Indonesia itu, karena terjadi kekacauan dalam berbahasa, berbudaya, dan bahkan pembangunan. Pembangunan yang tetap mengedepankan filosofi-filosofi Indonesia, sehingga tidak hanya terbentuk bangunan, seni, hasil karya namun tetap berkarakter, karena mengikuti aturan filosofi Indonesia.

\section{Karakter}

Pandangan para ahli beragam tentang karakter. Ada yang berpendapat bahwa karakter merupakan suatu penilaian yang subyektif terhadap kualitas moral dan mental. Ahli lain mengatakan bahwa karakter sebagai penilaian subyektif terhadap kualitas mental saja. Oleh karena itu upaya merubah atau membentuk karakter hanya berkaitan dengan stimulasi terhadap intelektual seseorang (encyclopedia. 2004). Sedangkan Coon (1983) mendefinisikan karakter sebagai suatu penilaian subyektif terhadap kepribadian seseorang yang berkaitan dengan atribut kepribadian yang dapat atau tidak dapat diterima oleh masyarakat. Menurut Megawangi (2003), kualitas karakter meliputi sembilan pilar, yaitu (1) Cinta Tuhan dan segenap ciptaan-Nya; (2) Tanggung jawab, Disiplin dan Mandiri; (3) Jujur/amanah dan Arif; (4) Hormat dan Santun; (5) Dermawan, Suka menolong, dan Gotong-royong; (6) Percaya diri, Kreatif dan Pekerja keras; (7) Kepemimpinan dan adil; (8) Baik dan rendah hati; (9) Toleran, cinta damai dan 
kesatuan. Jadi, menurut Ratna Megawangi, orang yang memiliki karakter baik adalah orang yang memiliki kesembilan pilar karakter tersebut.

Pendapat para ahli di atas dapat dikemukakan bahwa karakter dipandang sebagai suatu yang sempit dan berpandangan luas. Pandangan sempit mengatakan bahwa karakter merupakan penilaian subyektif terhadap mental seseorang. Sedangkan ahli yang berpandangan luas mengatakan karakter merupakan penilaian subyektif terhadap kualitas moral dan mental, bahkan diutarakan menjadi sembilan pilar oleh Megawangi. Semua itu adalah aspek-aspek kepribadian seseorang dalam hidup sebagai pribadi dan kehidupan sosial.

Perkembangan karakter pada setiap individu dipengaruhi oleh faktor bawaan (nature) dan faktor lingkungan (nurture). Menurut para developmental psychologist, setiap manusia memiliki potensi bawaan yang akan termanisfestasi setelah dia dilahirkan, termasuk potensi yang terkait dengan karakter atau nilainilai kebajikan. Menurut Confusius bahwa manusia pada dasarnya memiliki potensi mencintai kebajikan, namun bila potensi ini tidak diikuti dengan pendidikan dan sosialisasi setelah manusia dilahirkan, maka manusia dapat berubah menjadi binatang, bahkan lebih buruk lagi (Megawangi, 2003). Oleh karena itu, proses sosialisasi dan pendidikan anak yang berkaitan dengan nilainilai kebajikan, baik di dalam keluarga, sekolah, maupun masyarakat (lingkungan) yang lebih luas sangat penting bagi pembentukan karakter sseeorang.

Proses sosialisasi dan pendidikan (faktor nurture) sangat penting dalam pendidikan karakter. Menurut Thomas Lichona (Megawangi, 2003), pendidikan karakter penting dilakukan sejak usia dini. Erik Erikson juga menyatakan hal yang sama ia menyebutkan bahwa anak adalah gambaran awal manusia menjadi manusia, yaitu masa di mana kebajikan berkembang secara perlahan tapi pasti (dalam Hurlock, 1981). Dengan kata lain bahwa apabila dasar-dasar kebajikan gagal ditanamkan pada anak di usia dini, maka dia akan menjadi orang dewasa yang tidak memiliki nilai-nilai kebajikan. Selanjutnya, White (dalam Hurlock, 1981)menyatakan bahwa usia dua tahun pertama dalam kehidupan adalah masa kritis bagi pembentukan pola penyesuaian personal dan sosial. 
Dapat disimpulkan bahwa karakter merupakan kualitas moral dan mental seseorang yang pembentukannya dipengaruhi oleh faktor bawaan (fitrah - nature) dan lingkungan (sosialisasi atau pendikan - nurture). Potensi karakter yang baik dimiliki manusia sebelum dilahirkan, tetapi potensi tersebut harus diisi nilai-nilai kebajikan secara terus-menerus melalui proses sosialisasi dan pendidikan sejak dini. Betapa penting dan urgennya proses sosialisasi dan pendidikan bagi perkembangan karakter anak sejak dini, karena belajar sepanjang hayat. Apabila salah dalam menanamkan nilai-nilai kehidupan kepada anak usia dini, maka ia akan dewasa dapat nilai yang benar untuk menuntunya menjadi harmonis atau akan rusak selamanya. Pendidikan itu yang utama dan pertama adalah di dalam keluarga.

Pada hakikatnya bahwa tugas dasar perkembangan seseorang adalah mengembangkan pemahaman yang benar tentang bagaimana dunia ini bekerja. Dengan kata lain, tugas utama seseorang dalam perkembangannya adalah mempelajari "aturan main" segala aspek yang ada di dunia ini. Selain itu, anak juga harus belajar memahami aturan main dalam hubungan kemasyarakatan, sehingga ada hukum dan sanksi yang mengatur perilaku anggota masyarakat dalam kehidupan bermasyarakat.

Menurut Garbarino \& Brofenbrenner (dalam Vasta, 1992), jika suatu bangsa ingin bertahan hidup, maka bangsa tersebut harus memiliki aturan-aturan yang menetapkan apa yang salah dan apa yang benar, apa yang boleh dan apa yang tidak boleh dilakukan, apa yang adil dan apa yang tidak adil, apa yang patut dan tidak patut. Oleh karena itu, sebagai makhluk sosial perlu ada aturan, norma, kaidah, hukum yang mengatur etika dan tingkahlaku dalam bicara, berlalu lintas, dan aktivitas sosial lainnya. Jika tidak, maka hidup ini akan "kacau", karena setiap orang boleh berlaku sesuai keinginannya masing-masing tanpa harus mempedulikan orang lain (makhluk individu). Akhirnya antar sesama menjadi saling menjegal, saling menyakiti, bahkan saling membunuh, sehingga hancurlah bangsa itu.

Memahami "aturan" dalam kehidupan di dunia dan menginternalisasikan dalam dirinya sehingga mampu mengaplikasikan "aturan" tersebut dalam 
kehidupan sehari-hari dengan sebaik-baiknya merupakan tugas setiap anak dalam perkembangannya. Kebiasaan membuang sampah pada tempatnya, antri, tidak menyeberang jalan dan parkir sembarangan, tidak merugikan atau menyakiti orang lain, mandiri (tidak memerlukan supervisi) serta perilaku-perilaku lain yang menunjukkan adanya pemahaman yang baik terhadap aturan sosial merupakan hasil dari perkembangan kualitas moral dan mental seseorang yang disebut karakter.

Menurut Megawangi (2003), anak-anak akan tumbuh menjadi pribadi yang berkarakter apabila dapat tumbuh pada lingkungan yang berkarakter, sehingga hakikat setiap anak yang dilahirkan suci dapat berkembang segara optimal. Mengingat lingkungan anak bukan saja lingkungan keluarga yang sifatnya mikro, maka semua pihak: keluarga, sekolah, media massa, komunitas bisnis, dan sebagainya, turut andil dalam perkembangan karakter anak. Dengan kata lain, mengembangkan generasi penerus berkarakter baik adalah tanggung jawab semua pihak. diperlukan kesadaran dari semua pihak bahwa pendidikan karakter merupakan suatu yang sangat penting untuk segera dilakukan. Kondisi karakter bangsa ini yang memprihatinkan, dan manusia tidak secara alamiah tumbuh menjadi manusia yang berkarakter baik, sebab menurut Aristoteles (dalam Megawangi, 2003), karakter merupakan hasil dari usaha seumur hidup individu dan masyarakat.

Dalam membentuk karakter anak diperlukan syarat-syarat mendasar bagi terbentuknya kepribadian yang baik. Menurut Megawangi (2003), ada tiga kebutuhan dasar anak yang harus dipenuhi, yaitu maternal bonding, rasa aman, dan stimulasi fisik dan mental. Maternal bonding (kelekatan psikologis dengan ibunya) merupakan dasar penting dalam pembentukan karakter anak karena aspek ini berperan dalam pembentukan dasar kepercayaan kepada orang lain (trust) pada anak. Kelekatan ini membuat anak merasa diperhatikan dan menumbuhkan rasa aman sehingga menumbuhkan rasa percaya. Menurut Erikson, dasar kepercayaan yang ditumbuhkan melalui hubungan ibu-anak pada tahun-tahun pertama kehidupan anak akan memberi bekal bagi kesuksesan anak dalam kehidupan sosialnya ketika ia dewasa. Dengan kata lain, ikatan emosional yang 
erat antara ibu-anak di usia awal dapat membentuk kepribadian yang baik pada anak.

Kebutuhan akan rasa aman yaitu kebutuhan anak akan lingkungan yang stabil dan aman. Kebutuhan ini penting bagi pembentukan karakter anak karena lingkungan yang berubah-ubah akan membahayakan perkembangan emosi bayi. Pengasuh yang berganti-ganti juga akan berpengaruh negatif pada perkembangan emosi anak. Menurut Bowlby (dalam Megawangi, 2003), normal bagi seorang bayi untuk mencari kontak dengan hanya satu orang (biasanya ibu) pada tahaptahap awal masa bayi. Kekacauan emosi anak yang terjadi karena tidak adanya rasa aman ini diduga oleh para ahli gizi berkaitan dengan masalah kesulitan makan pada anak. Tentu saja hal ini tidak kondusif bagi pertumbuhan anak yang optimal.

Kebutuhan akan stimulasi fisik dan mental juga merupakan aspek penting dalam pembentukan karakter anak. Tentu saja hal ini membutuhkan perhatian yang besar dari orang tua dan reaksi timbal balik antara ibu dan anaknya. Menurut pakar pendidikan anak, seorang ibu yang sangat perhatian (yang diukur dari seringnya ibu melihat mata anaknya, mengelus, menggendong, dan berbicara kepada anaknya) terhadap anaknya yang berusia usia di bawah enam bulan akan mempengaruhi sikap bayinya sehingga menjadi anak yang gembira, antusias mengeksplorasi lingkungannya, dan menjadikannya anak yang kreatif.

\section{Keluarga}

Pandangan para sosiolog bahwa keluarga memiliki peran penting dalam menentukan kemajuan suatu bangsa, sehingga mereka berteori bahwa keluarga adalah unit yang penting sekali dalam masyarakat. Jikalau keluarga-keluarga yang merupakan fondasi masyarakat lemah, maka masyarakat pun akan lemah. Para sosiolog meyakini bahwa berbagai masalah yang terjadi di masyarakat, seperti kejahatan seksual dan kekerasan yang merajalela, serta segala macam perilaku menyimpang merupakan akibat dari lemahnya institusi keluarga.

Keluarga merupakan tempat pertama dan utama bagi pertumbuhan dan perkembangan seorang anak. Menurut Majelis Umum PBB (dalam Megawangi, 2003), bahwa fungsi utama keluarga adalah "sebagai wahana untuk mendidik, 
mengasuh, dan mensosialisasikan anak, mengembangkan kemampuan seluruh anggotanya agar dapat menjalankan fungsinya di masyarakat dengan baik, serta memberikan kepuasan dan lingkungan yang sehat guna tercapainya keluarga, sejahtera". Sedangkan menurut pakar pendidikan, William Bennett (dalam Megawangi, 2003), bahwa keluarga merupakan tempat yang paling awal dan efektif untuk menjalankan fungsi Departemen Kesehatan, Pendidikan, dan Kesejahteraan. Apabila keluarga gagal untuk mengajarkan kejujuran, semangat, keinginan untuk menjadi yang terbaik, dan kemampuan-kemampuan dasar, maka akan sulit sekali bagi institusi-institusi lain untuk memperbaiki kegagalankegagalannya.

Dari pendapat di atas dapat disimpulkan bahwa keluarga merupakan wahana pertama dan utama bagi pendidikan karakter anak. Apabila keluarga gagal melakukan pendidikan karakter pada anak-anaknya, maka akan sulit bagi institusi-institusi lain di luar keluarga (termasuk sekolah) untuk memperbaikinya. Kegagalan keluarga dalam membentuk karakter anak akan berakibat pada tumbuhnya masyarakat yang tidak berkarakter. Oleh karena itu, setiap keluarga harus memiliki kesadaran bahwa karakter bangsa sangat tergantung pada pendidikan karakter anak di dalam keluarga.

Keberhasilan keluarga dalam menanamkan nilai-nilai kebajikan pada anak sangat tergantung pada pola asuh yang diterapkan orang tua pada anaknya. Pola asuh dapat didefinisikan sebagai pola interaksi antara anak dengan orangtua yang meliputi pemenuhan kebutuhan fisik (seperti makan, minum dan lain-lain) dan kebutuhan psikologis (seperti rasa aman, kasih sayang dan lain-lain), serta sosialisasi norma-norma yang berlaku di masyarakat agar anak dapat hidup selaras dengan lingkungannya. Dengan kata lain, pola asuh juga meliputi pola interaksi orang tua dengan anak dalam rangka pendidikan karakter anak.

Secara umum, Baumrind mengkategorikan pola asuh menjadi tiga jenis, yaitu : (1) Pola asuh Authoritarian, (2) Pola asuh Authoritative, (3) Pola asuh permissive. Tiga jenis pola asuh Baumrind ini hampir sama dengan jenis pola asuh menurut Hurlock juga Hardy \& Heyes yaitu: (1) Pola asuh otoriter, (2) Pola asuh demokratis, dan (3) Pola asuh permisif. Pola asuh yang diterapkan oleh 
orang tua dari ciri-ciri masing-masing pola asuh tersebut, yaitu sebagai berikut : Pola asuh otoriter mempunyai ciri : 1) Kekuasaan orangtua dominan; 2) Anak tidak diakui sebagai pribadi; 3) Kontrol terhadap tingkah laku anak sangat ketat; dan 4) Orangtua menghukum anak, jika anak tidak patuh. Pola asuh demokratis mempunyai ciri : 1) Ada kerjasama antara orangtua dan anak; 2) Anak diakui sebagai pribadi; 3) Ada bimbingan dan pengarahan dari orangtua; dan 4) Ada kontrol dari orangtua yang tidak kaku. Pola asuh permisif mempunyai ciri : 1) Dominasi pada anak; 2) Sikap longgar atau kebebasan dari orangtua; 3) Tidak ada bimbingan dan) pengarahan dari orangtua; dan 4) Kontrol dan perhatian orangtua sangat kurang.

Melalui pola asuh yang dilakukan oleh orang tua, anak belajar tentang banyak hal, termasuk karakter. Tentu saja pola asuh otoriter (yang cenderung menuntut anak untuk patuh terhadap segala keputusan orang tua) dan pola asuh permisif (yang cenderung memberikan kebebasan penuh pada anak untuk berbuat) sangat berbeda dampaknya dengan pola asuh demokratis (yang cenderung mendorong anak untuk terbuka, namun bertanggung jawab dan mandiri) terhadap hasil pendidikan karakter anak. Artinya, jenis pola asuh yang diterapkan oleh orang tua terhadap anaknya menentukan keberhasilan pendidikan karakter anak oleh keluarga.

Pola asuh otoriter cenderung membatasi perilaku kasih sayang, sentuhan, dan kelekatan emosi orangtua - anak sehingga antara orang tua dan anak seakan memiliki dinding pembatas yang memisahkan "si otoriter" (orang tua) dengan "si patuh" (anak). Studi yang dilakukan oleh Fagan (dalam Badingah, 1993) menunjukan bahwa ada keterkaitan antara faktor keluarga dan tingkat kenakalan keluarga, di mana keluarga yang broken home, kurangnya kebersamaan dan interaksi antar keluarga, dan orang tua yang otoriter cenderung menghasilkan remaja yang bermasalah. Pada akhirnya, hal ini akan berpengaruh terhadap kualitas karakter anak.

Pola asuh permisif yang cenderung memberi kebebesan terhadap anak untuk berbuat apa saja sangat tidak kondusif bagi pembentukan karakter anak. Bagaimana pun anak tetap memerlukan arahan dari orang tua untuk mengenal 
mana yang baik mana yang salah. Dengan memberi kebebasan yang berlebihan, apalagi terkesan membiarkan, akan membuat anak bingung dan berpotensi salah arah.

Pola asuh demokratis tampaknya lebih kondusif dalam pendidikan karakter anak. Hal ini dapat dilihat dari hasil penelitian yang dilakukan oleh Baumrind yang menunjukkan bahwa orangtua yang demokratis lebih mendukung perkembangan anak terutama dalam kemandirian dan tanggungjawab. Sementara, orangtua yang otoriter merugikan, karena anak tidak mandiri, kurang tanggungjawab serta agresif, sedangkan orangtua yang permisif mengakibatkan anak kurang mampu dalam menyesuaikan diri di luar rumah. Menurut Arkoff (dalam Badingah, 1993), anak yang dididik dengan cara demokratis cenderung mengungkapkan agresivitasnya dalam tindakan-tindakan yang konstruktif atau dalam bentuk kebencian yang sifatnya sementara saja. Di sisi lain, anak yang dididik secara otoriter atau ditolak memiliki kecenderungan untuk mengungkapkan agresivitasnya dalam bentuk tindakan-tindakan yang merugikan. Sementara itu, anak yang dididik secara permisif cenderung mengembangkan tingkah laku agresif secara terbuka atau terang-terangan.

Menurut Middlebrook (dalam Badingah, 1993), hukuman fisik yang umum diterapkan dalam pola asuh otoriter kurang efektif untuk membentuk tingkah laku anak karena : (a) menyebabkan marah dan frustasi (dan ini tidak cocok untuk belajar); (b) adanya perasaan-perasaan menyakitkan yang mendorong tingkah laku agresif; (c) akibat-akibat hukuman itu dapat meluas sasarannya, misalnya anak menahan diri untuk memukul atau merusak pada waktu ada orangtua tetapi segera melakukan setelah orangtua tidak ada; (d) tingkah laku agresif orangtua menjadi model bagi anak.

Hasil penelitian Rohner (dalam Megawangi, 2003) menunjukkan bahwa pengalaman masa kecil seseorang sangat mempengaruhi perkembangan kepribadiannya (karakter atau kecerdasan emosinya). Penelitian tersebut - yang menggunakan teori PAR (Parental Acceptance-Rejection Theory)- menunjukkan bahwa pola asuh orang tua, baik yang menerima (acceptance) atau yang menolak 
(rejection) anaknya, akan mempengaruhi perkembangan emosi, perilaku, sosialkognitif, dan kesehatan fungsi psikologisnya ketika dewasa kelak.

Dalam hal ini, yang dimaksud dengan anak yang diterima adalah anak yang diberikan kasih sayang, baik secara verbal (diberikan kata-kata cinta dan kasih sayang, kata-kata yang membesarkan hati, dorongan, dan pujian), maupun secara fisik (diberi ciuman, elusan di kepala, pelukan, dan kontak mata yang mesra). Sementara, anak yang ditolak adalah anak yang mendapat perilaku agresif orang tua, baik secara verbal (kata-kata kasar, sindiran negatif, bentakan, dan kata-kata lainnya yang dapat mengecilkan hati), ataupun secara fisik (memukul, mencubit, atau menampar). Sifat penolakan orang tua dapat juga bersifat indifeerence atau neglect, yaitu sifat yang tidak mepedulikan kebutuhan anak baik fisik maupun batin, atau bersifat undifferentiated rejection, yaitu sifat penolakan yang tidak terlalu tegas terlihat, tetapi anak merasa tidak dicintai dan diterima oleh orang tua, walaupun orang tua tidak merasa demikian.

Hasil penelitian Rohner menunjukkan bahwa pola asuh orang tua yang menerima membuat anak merasa disayang, dilindungi, dianggap berharga, dan diberi dukungan oleh orang tuanya. Pola asuh ini sangat kondusif mendukung pembentukan kepribadian yang pro-sosial, percaya diri, dan mandiri namun sangat peduli dengan lingkungannya. Sementara itu, pola asuh yang menolak dapat membuat anak merasa tidak diterima, tidak disayang, dikecilkan, bahkan dibenci oleh orang tuanya. Anak-anak yang mengalami penolakan dari orang tuanya akan menjadi pribadi yang tidak mandiri, atau kelihatan mandiri tetapi tidak mempedulikan orang lain. Selain itu anak ini akan cepat tersinggung, dan berpandangan negatif terhadap orang lain dan terhadap kehidupannya, bersikap sangat agresif kepada orang lain, atau merasa minder dan tidak merasa dirinya berharga.

Dari paparan di atas jelas bahwa jenis pola asuh yang diterapkan orang tua kepada anaknya sangat menentukan keberhasilan pendidikan karakter anak. Kesalahan dalam pengasuhan anak akan berakibat pada kegagalan dalam pembentukan karakter yang baik. Menurut Megawangi (2003) ada beberapa kesalahan orang tua dalam mendidik anak yang dapat mempengaruhi 
perkembangan kecerdasan emosi anak sehingga berakibat pada pembentukan karakternya, yaitu :

1. Kurang menunjukkan ekspresi kasih sayang baik secara verbal maupun fisik.

2. Kurang meluangkan waktu yang cukup untuk anaknya.

3. Bersikap kasar secara verbal, misainya menyindir, mengecilkan anak, dan berkata-kata kasar.

4. Bersikap kasar secara fisik, misalnya memukul, mencubit, dan memberikan hukuman badan lainnya.

5. Terlalu memaksa anak untuk menguasai kemampuan kognitif secara dini.

6. Tidak menanamkan "good character' kepada anak.

Dampak yang ditimbulkan dari salah asuh seperti di atas, menurut Megawangi akan menghasilkan anak-anak yang mempunyai kepribadian bermasalah atau mempunyai kecerdasan emosi rendah.

1. Anak menjadi acuh tak acuh, tidak butuh orang lain, dan tidak dapat menerima persahabatan. Karena sejak kecil mengalami kemarahan, rasa tidak percaya, dan gangguan emosi negatif lainnya. Ketika dewasa ia akan menolak dukungan, simpati, cinta dan respons positif lainnya dari orang di sekitarnya. la kelihatan sangat mandiri, tetapi tidak hangat dan tidak disenangi oleh orang lain.

2. Secara emosiol tidak responsif, dimana anak yang ditolak akan tidak mampu memberikan cinta kepada orang lain.

3. Berperilaku agresif, yaitu selalu ingin menyakiti orang baik secara verbal maupun fisik.

4. Menjadi minder, merasa diri tidak berharga dan berguna.

5. Selalu berpandangan negatif pada lingkungan sekitarnya, seperti rasa tidak aman, khawatir, minder, curiga dengan orang lain, dan merasa orang lain sedang mengkritiknya.

6. Ketidakstabilan emosional, yaitu tidak toleran atau tidak tahan terhadap stress, mudah tersinggung, mudah marah, dan sifat yang tidak dapat diprediksi oleh orang. lain. 
7. Keseimbangan antara perkembangan emosional dan intelektual. Dampak negatif lainnya dapat berupa mogok belajar, dan bahkan dapat memicu kenakalan remaja, tawuran, dan lainnya.

8. Orang tua yang tidak memberikan rasa aman dan terlalu menekan anak, akan membuat anak merasa tidak dekat, dan tidak menjadikan orang tuannya sebagai "role model" Anak akan lebih percaya kepada "peer group"nya sehingga mudah terpengaruh dengan pergaulan negatif.

\section{Simpulan.}

Karakter merupakan kualitas moral dan mental seseorang yang pembentukannya dipengaruhi oleh faktor bawaan (fitrah - nature) dan lingkungan (sosialisasi atau pendikan - nurture). Potensi karakter yang baik dimiliki manusia sebelum dilahirkan, tetapi potensi tersebut harus terus-menerus dibina melalui sosialisasi dan pendidikan sejak usia dini.

Meskipun semua pihak bertanggung jawab atas pendidikan karakter calon generasi penerus bangsa (anak-anak), namun keluarga merupakan wahana pertama dan utama bagi pendidikan karakter anak. Untuk membentuk karakter anak keluarga harus memenuhi tiga syarat dasar bagi terbentuknya kepribadian yang baik, yaitu maternal bonding, rasa aman, dan stimulasi fisik dan mental. Selain itu, jenis pola asuh yang diterapkan orang tua kepada anaknya juga menentukan keberhasilan pendidikan karakter anak di rumah. Kesalahan dalam pengasuhan anak di keluarga akan berakibat pada kegagalan dalam pembentukan karakter yang baik.

Kegagalan keluarga dalam melakukan pendidikan karakter pada anakanaknya, akan mempersulit institusi-institusi lain di luar keluarga (termasuk sekolah) dalam upaya memperbaikinya. Kegagalan keluarga dalam membentuk karakter anak akan berakibat pada tumbuhnya masyarakat yang tidak berkarakter. Oleh karena itu, setiap keluarga harus memiliki kesadaran bahwa karakter bangsa sangat tergantung pada pendidikan karakter anak-anak mereka dalam keluarga. 


\section{DAFTAR PUSTAKA}

Badingah, S. (1993). Agresivitas Remaja Kaitannya dengan Pola Asuh, Tingkah Laku Agresif Orang Tua dan Kegemaran Menonoton Film Keras. Program Studi Psikologi - Pascasarjana, UI. Depok.

Coon, Dennis. (1983). Introduction to Psychology : Exploration and Aplication. West Publishing Co.

http://encyclopedia.thefreedictionary.com. Diakses tanggal 26 April 2004.

Hurlock, E.B. 1981. Child Development. Sixth Edition. McGraw Hill Kogakusha International Student.

Megawangi, Ratna. (2003). Pendidikan Karakter untuk Membangun Masyarakat Madani. IPPK Indonesia Heritage Foundation.

Vasta, Ross, at all. (1992). Child Psychology : The Modern Science. John Wiley \& Sons Inc. 